\title{
The Relationship Between School Principals’ Leadership Styles and Teachers’ Achievement Motivation
}

\author{
Heba Alfahad, Salem Alhajeri, Abdulmuhsen Alqahtani \\ Kuwait University, Kuwait, Kuwait
}

\begin{abstract}
School principals' leadership styles play a major role in teachers' performance. This paper examines the relationship between school principals' leadership styles, whether transformational or transactional, and teachers' achievement motivation. Using the quantitative methodology, a total of 320 heads of instructional departments were randomly selected from randomly selected schools. The results revealed that a transformational leadership style was prevalent among principals, and teachers' achievement motivation was positive. There was a positive correlation between the principals' transformational leadership style and the teachers' achievement motivation. Relevant recommendations are included.
\end{abstract}

Keywords: leadership styles, transformational, transactional, achievement motivation

\section{Leadership Styles and Achievement Motivation}

An institutions' success is measured by its administration and achievements. Therefore, administrations need efficient leaders to take them toward that success. In this sense, leadership style is one of the main factors determining the effectiveness of any leader. Leadership style reflects a manager or leader's personality and how he or she manages work, which affects the performance of institutions as well as employees (Lwasif, 1995). However, Subramaniam (2011) pointed out the importance of studying leadership styles because of its significance in an institution's success. The educational process is to achieve its goals, it needs teachers with high achievement motivation. At the same time, teachers need support to increase their satisfaction and motivation, and this will come about through principals' effective leadership style (Johnson, 2007). Achievement motivation is a behavior connected to performance excellence, and this is what we are looking for in our educational institutions. In addition, motivation is a main factor in being successful in any job (Eres, 2011).

The human element is considered one of the most productive elements in society, because human forces are the basic power toward creation and development. Thus, the skills of leadership are considered the base of administrative operations. Some people define leadership as an activity or influence operation that the leader carries out with his or her employees to encourage them to achieve the proposed purposes. Pfinffner and Preshtus defined leadership as "a kind of moral spirit and responsibility in the leader, which is led to

Heba Alfahad, Graduate Student, Educational Management and Planning Department, Kuwait University.

Salem Alhajeri, Ph.D., Faculty member, College of Education, Kuwait University.

Abdulmuhsen Alqahtani, Ph.D., Faculty member, College of Education, Kuwait University.

Correspondence concerning this article should be addressed to Heba Alfahad, Bayan, Block 5, St 2, House 12, Kuwait. E-mail: heba_s33@hotmail.com. 
unifying the efforts of the employees in order to achieve goals which exceed personal interests” (Hamadat, 2006, p. 16).

Sauer (2011) confirmed the importance of leadership and its effect on the performance of employees. Sauer's study explained the importance of leadership behavior and how the leader's performance style will affect the organization. Danish, Malik, and Munir (2011) discussed the effect of leadership and a manager's style, showing that these had a significant effect on the administration and its effectiveness.

\section{Leadership Styles}

Leadership styles vary depending on the character of the leader. Each character has its style, so that leadership styles can be described as "the kind of behavior and abilities which the manager has and which enables him to interact with the employees to achieve goals” (Hesham, 2010, p. 39).

The transformational leadership style. Burns was the first to define the transformational and transactional leadership styles in 1978. Transformational leadership is the process in which the leader and employee support each other to reach a high level of moral and supportive spirit (Ayaserah, 2006).

Leithwood defined it as "a kind of group force which is apparent within others instead of above others". Fink and Stoll said that it is the individual's ability to reach his or her vision and transfer it to others (Aljabr, 2010). Transformational leaders have the ability to develop the vision of their employees, encourage them, and raise their moral spirit (Neider \& Schriesheim, 2002). Transformational leaders inspire trust in those they are leading, encouraging them to think critically and seek new ways to approach their jobs. Transformational leaders motivate by making followers more aware of the importance of task outcomes (Akpa, Nwankwere, Obiwuru, \& Okwu, 2011). As a result, there is an increase in their levels of performance and commitment to the goals of their organization in a positive way (Hiller, Resick, Weingarden, \& Whitman, 2009). However, Fenn and Mixon (2011) confirmed that the transformational style raises the efficiency and productivity of an organization because of its flexibility and how it gives the followers the chance to be creative.

Transformational leadership has four components: charisma, inspirational motivation, intellectual stimulation, and individual consideration.

The transactional leadership style. Transaction leadership involves an exchange process between leader and follower. The leader focuses on results and performing; moreover, he or she motivates employees by bonuses in order to make them work, and uses punishment if they do it wrong (Aldeb, 2012). Alomri (2009) said that transactional leaders are good at making issues clear, but they lack some positive skills such as giving attention to the needs of individuals.

Bono and Judge (2004) described the transactional factors as:

- Contingent rewards;

- Management by exception-passive;

- Management by exception-active.

\section{Achievement Motivation}

The American psychologist Murry was the first to introduce the concept of need to achieve, by describing it as an important personal component. Murry defined the need to achieve as referring to the desire to overcome obstacles and struggling to do difficult tasks perfectly and fast (Khalifa, 2006).

Researchers became interested with the concept based on the following (Yones, 2007):

(1) There is a positive correlation between the professional status of the person and his or her achievement 
motivation;

(2) Understanding the achievement motivation helps in determining the social and psychological variations that influence individual personality;

(3) It enables us to know a person's level of satisfaction toward his or her motive.

A study for Isaac, Pitt, and Zerbe (2001) mentioned that the level of performance of the employees increases in a motivating environment, inspiring individuals to achieve levels of performance beyond their expectations. Therefore, leaders must take action to satisfy employees and increase their motivation. After having their motivations improved, employees will work harder and feel responsible for achieving targets and goals (Almansour, 2012).

\section{Statement of the Problem}

The current study aims to examine the relationship between school principals' leadership styles, whether transformational or transactional, and teachers' achievement motivation. More specifically, based on the heads of instructional departments' perceptions, it attempts to answer the following research questions:

(1) Which leadership style is prevalent among intermediate school principals in Kuwait?

(2) Do the heads of instructional departments differ in their perceptions about school principals' leadership styles in light of their length of work period, career development programs, and sex?

(3) What is the achievement motivation level among teachers in intermediate schools in Kuwait?

(4) Do the heads of instructional departments differ in their perceptions about teachers' achievement motivation in light of their length of work period, career development programs, and sex?

(5) Is there a correlation between school principals' leadership style and teachers' achievement motivation?

Therefore, knowing leadership style may provide insight into how to increase achievement with a high standard of efficiency by boosting the appropriate leadership style. It is believed that following an appropriate leadership style can improve achievement motivation, which in turn will increase the level of productivity. Of course, the obtained data will contribute to creating a clearer picture of what plans and programs are required to enhance an organization's performance.

\section{Research Method}

\section{Research Subject}

The study sample was randomly selected, representing the population of heads of instructional departments within the intermediate school level in the State of Kuwait in the second semester 2012. The heads, not the principals or teachers, were decided upon because they were believed to be in a position to give a gestalt of the whole phenomenon. The sample demographic characteristics were: sex (142 males and 148 females); service period (15\%, 5-10 years; 32\%, 11-15 years; and 53\%, 16 years plus); educational area (44 Hawalli, 45 Alasima, 40 Mubarak Alkabeer, 49 Alfarwaneyah, 55 Aljahra, and 57 Alahmadi); and number of career development programs (1.4\%, none; 29.6\%, 1-5; 32.4\%, 6-10; and 36.6\%, 11 plus).

Having obtained the required permissions, the questionnaires were distributed by the researchers among the participants. When the questionnaires were collected back, invalid questionnaires (i.e., questionnaires with missing data) were excluded. The clean questionnaires were codified and processed, using the Statistical Package for the Social Science (SPSS). 


\section{Measurement}

The current study used the Arabic version of Multifactor Leadership Questionnaire (MLQ) developed by Bass and Avolio (Alhelali, 2001) to measure transformational and transactional leadership. It was modified to suit the Kuwaiti context. In addition, achievement motivation was measured, using the instrument developed by Alqabbali's (2009) study. The questionnaire is divided into three sections:

- Section one includes demographic information: sex, service period, educational area, and a number of career development programs;

- Section two measures transformational leadership style (idealized influence, inspirational motivation, intellectual stimulation, and individualized consideration) and transactional leadership style (contingent rewards, management by exception—passive, and management by exception—active);

- Section three measures teachers' achievement motivation (perseverance, achieving goals, and ambition).

The responses were measured on a five-point Likert-type scale, anchored on " 5 = always, $4=$ often, 3 = sometimes, 2 = rarely, 1 = never" for positively phrased statements and anchored on " 1 = always, 2 = often, 3 = sometimes, 4 = rarely, 5 = never” for negatively phrased statements. The higher the score, the higher the level of agreement. The instruments used were tested for reliability and clarity. The reliability coefficient for MLQ was 0.88 , achievement motivation was 0.92 , indicating the instruments were reliable. No negative feedback was reported with respect to the clarity of the instruments used, indicating that the statements were clear and understandable.

\section{Findings}

The findings are reported according to the research question sequence, starting with the first question.

\section{Question 1}

The findings showed that the heads of instructional departments perceived their school principals to be employing the two leadership styles to a considerable degree. However, those school principals used the transformation style $(M=4.3 ; S D=0.5)$ a bit more than the transactional style $(M=4.1 ; S D=0.6)$. Although the transformational style was preferred by the school principals, as perceived by the participants, the existence of the two styles could be due to the fact that there was no single style used across all contexts and situations.

\section{Question 2}

The findings showed that there were no statistically significant differences among the participants' perceptions concerning their school principals' leadership transformational styles in terms of sex $(F=1.05$; $p=0.39)$ and length of the work period $(F=1.04 ; p=0.42)$, and career development programs $(F=0.63 ; p=$ $0.93)$; and transactional leadership style in terms of $\operatorname{sex}(F=0.97 ; p=0.52)$, and length of work period $(F=$ $0.900 ; p=0.66$ ), and career development programs $(F=0.82 ; p=0.78)$. These findings reveal that, regardless of the heads of instructional departments' demographic characteristics, they perceived both leadership styles to be existent and exercised.

\section{Question 3}

The findings showed that the heads of instructional departments perceived their teachers' achievement at moderately high $(M=3.9 ; S D=0.5)$. More specifically, the teachers' perceived perseverance was the highest ( $M$ $=4.0 ; S D=0.58$ ), achieving goals was $M=3.9 ; S D=0.59$, and ambition was $M=3.8 ; S D=0.6$. It is clear that, based on these results, there is a kind of achievement motivation in Kuwaiti teachers in intermediate schools. 


\section{Question 4}

The findings showed that there were no statistically significant differences among the participants' perceptions concerning their teachers' achievement motivation in terms of $\operatorname{sex}(F=1.1 ; p=0.30)$ and length of the work period ( $F=1.15 ; p=0.22)$, and career development programs $(F=0.90 ; p=0.69)$. These findings reveal that, regardless of the heads of instructional departments' demographic characteristics, they perceived that Kuwaiti teachers in intermediate schools were motivated to achieve.

\section{Question 5}

The findings showed that there were statistically significant correlations between school principals' leadership styles and teachers' achievement motivation, all as perceived by the heads of the instructional departments. That is, there were statistically significant correlations between teachers' achievement motivation and school principals' transformational leadership ( $r=0.46, p=0.000)$; and transactional style $(r=0.38, p=$ 0.000). These significant correlations indicate that transformational leadership style had a stronger relationship with teachers' achievement motivation than the transactional leadership style.

\section{Conclusions}

The current study aimed to explore the perceptions of heads of instructional departments about the relationship between prevailing leadership styles used by their principals and teachers' achievement motivation. Obtained findings showed that both styles were used and teachers were motivated to achieve, and that both styles were significantly positively correlated with teachers' achievement motivation. There was no effect for demographic factors with respect to perceptions of heads of instructional departments. Based on these findings, we can recommend that there is no single style claimed to be absolutely better than the other; that is, both styles should be used appropriately to enhance teachers' achievement motivation.

\section{References}

Akpa, V., Nwankwere, I., Obiwuru, T., \& Okwu, A. (2011). Effects of leadership style on organizational performance: A survey of selected small scale enterprises in Ikosi-Ketu council development area of Lagos State, Nigeria. Australian Journal of Business and Management Research, 1(7), 100-111.

Aldeb, S. (2012). Mada mumarasat Alqeyadat Aledareyah Alakadimiyah Bljam’at Alfalastineya Lelqeyadah Altahwileyah w su'obat'ha w Sobl Tanmeyat'ha (The extent of practicing transformational leadership by academic administrative leaders in Palestinian Universities and its difficulties and ways to develop it) (Unpublished Masters dissertation, Alazhar University, Gazza).

Alhelali, A. (2001). Estekhdam Nadhareyatai Alqeyadah Altahwileyah w Alqeyadah Alejra'eyah fi Ba'adh Alkoleyat Aljame'eyah (Using transformational leadership and transactional leadership theories in some universities' colleges). Journal of the Future of Arabic Education, 7(21), 1-46.

Aljabr, Z. (2010). Alqeyadah Altahwileyah w Altatwir Almehani Almustamer Lelmo'alemin (Transformational leadership and continuous career development for teachers). Kuwait University: Academic Publication Council.

Almansour, Y. (2012). The relationship between leadership styles and motivation of managers conceptual framework. Journal of Arts, Science and Commerce, 3(1), 161-166.

Alomri, Q. (2009). Anmat Alqeyadah Aledareyah w Ta'atheerha fi Enjah Almonadhamat Alhukomeyah (Administrative leadership styles and its impact on governments organizations) (Unpublished Ph.D. dissertation, Sant Clements University, Iraq).

Alqabbali, Y. (2009). Fa'eleyat Barnamaj Ethra'e qa'em ala Alal'aab Althakeyah fi Tatwir Maharat Hal Almushkelat w Aldafe'eyah Lelenjaz Lada Atalaba Almutafaweqin fi Asu'odeyah (The effectiveness of an enrichment program based on smart games in developing problems-solving skills and achievement motivation for superior students in Saudi) (Unpublished Ph.D. dissertation, Amman University, Jordan). 
Ayaserah, A. (2006). Alqeyadah w Aldafe'eyah fi Aledarah Altarbaweyah (Leadership and motivation in educational management). Amman: Dar Alhamed.

Bono, J., \& Judge, T. (2004). Personality and transformational and transactional leadership: A meta-analysis. Journal of Applied Psychology, 89, 901-910.

Danish, R., Malik, M., \& Munir, Y. (2011). The impact of leader’s emotional quotient on organizational effectiveness: Evidence from industrial and banking sectors of Pakistan. International Journal of Business and Social Science, 2, 114-118.

Eres, F. (2011). Relationship between teacher motivation and transformational leadership characteristics of school principals. International Journal of Education, 3, 1-11.

Fenn, W., \& Mixon, J. (2011). An examination of self-perceived transformational leadership behaviors of Texas superintendents. International Journal of Educational Leadership Preparation, 6, 1-14.

Hamadat, M. (2006). Alqeyadah Altarbaweyah Fi Alqarn Aljadid (Educational leadership in the new century). Amman: Dar Alhamed.

Hesham, A. (2010). Alqeyadah w Alaqat'ha Belredha Alwadhifi (Leadership and its relationship with job satisfaction). Amman: Dar Alyazori.

Hiller, N., Resick, C., Weingarden, S., \& Whitman, D. (2009). The bright-side and the dark-side of CEO personality: Examining core self-evaluations, narcissism, transformational leadership, and strategic influence. Journal of Applied Psychology, 94, 1365-1381.

Isaac, R., Pitt, D., \& Zerbe, W. (2001). Leadership and motivation: The effective application of expectancy theory. Journal of Managerial Issues, 13, 212-225.

Johnson, T. L. (2007). The impact of principal leadership styles on teacher motivation and job satisfaction (ProQuest dissertations and theses).

Khalifa, A. (2006). Meqyas Adafe'eyah Lelenjaz (Measurement for achievement motivation). Cairo: Dar Gharib.

Lwasif, S. (1995). Anmat ALqeyadah Fi Etar Altaghyir Altandhimi Lelmu'asasat Aljaza'ereyah (Leadership styles according to organizational change for Algerian institutions). Journal of Social Science, 23, 81-112.

Neider, L., \& Schriesheim, C. (2002). Leadership. Greenwich, C.T.: Information Age Publishing.

Sauer, S. (2011). Taking the reins: The effects of new leaders' status and leadership style on team performance. Journal of Applied Psychology, 96, 574-587.

Subramaniam, P. A. B. (2011). The influence of leadership style on organizational commitment (Unpublished Masters dissertation, University Utara, Malaysia).

Yones, M. (2007). Saykalojya Adafe'eya w Alenfe'alat (Psychology of motivation and emotions). Amman: Dar AlMasira. 